UDC $622.276+622.833$

Article / Статья

(c) PNRPU / ПНИПУ, 2020

\title{
Studying the Wellbore Stability Enhancement Mechanism during Drilling through Fractured Argillites
}

\section{Mariia V. Nutskova, Inna V. Chudinova, Aleksandr N. Sobolev}

Saint Petersburg Mining University (2 21st line, Vasilyevsky island, Saint Petersburg, 199106, Russian Federation)

\section{Исследование механизма повышения стабильности ствола скважины при бурении трещиноватых аргиллитов}

\section{М.В. Нуцкова, И.В. Чудинова, А.Н. Соболев}

Санкт-Петербургский горный университет (Россия, 199106, г. Санкт-Петербург, Васильевский остров, 21-я линия, 2)

Keywords:

well drilling, mudrock, argillite, hydration-active mudrock, Labaganskoye field, drilling problems, cavings, laboratory studies, dispersion ability, stability, drilling fluid, bridging agents, inhibitors, cationic polymers, Chenevert method.

Ключевые слова бурение скважин, глинистые породы, аргиллиты, гидратационно-активные глинистые породы, Лабаганское месторождение, осложнения, обвалообразование,

лабораторные исследования, диспергирующая способность, устойчивость, буровой раствор, кольматанты, ингибиторы, катионные полимеры, метод Ченеверта.
The paper presents the relevance of enhancing wellbore stability by developing and applying efficient drilling fluid compositions for well constructions in fractured argillite. In the process of well constructions, there comes a range of complications associated with instability of rocks forming borehole walls, which sometimes results in lower penetration rates, higher construction costs and well abandonment. Often, drilling problems occur at drilling through mudrocks that account for up to $70 \%$ of field sections. When using water-base drilling fluids, the mudrock swelling due to the contact with the fluid dispersion medium adversely affects the drilling process and can significantly increase well construction costs. The accumulation of wellbore cavings inhibits well circulation, causes landing of drilling tools and may result in tool sticking. An analysis of drilling problems in fractured argillite is presented; the mechanisms affecting open hole stability in the fractured argillite deposits are shown. The use of potassium chloride is recommended to enhance the stability of argillite-formed borehole walls. The results are supported by experimental studies using the Chenevert method, as well as fracture propping tests. When the argillite sample was placed in potassium chloride (KCl) solution, there was a minor fracture expansion and propagation over the entire sample length, which is a positive result. To enhance wellbore stability, further study approaches are proposed: upgrading mud by adding inhibiting compounds, such as salt solutions in combination with high-molecular polymer compositions.

Отражена актуальность повышения устойчивости ствола скважины за счет разработки и применения рациональных составов буровых растворов для строительства скважин в трещиноватых аргиллитах. В процессе сооружения скважины возникают разнообразные осложнения, сопряженные с неустойчивостью пород, слагающих стенки ствола скважины, что влечет за собой снижение скорости проходки, рост стоимости строительства, а в некоторых случаях приводит к ликвидации скважины. Зачастую осложнения проявляются в интервалах проходки глинистых пород, которые составляют до $70 \%$ разрезов месторождений. При использовании буровых растворов на водной основе набухание глинистых пород вследствие взаимодействия с дисперсионной средой раствора оказывает негативное влияние на процесс бурения и может значительно повысить стоимость строительства скважины. Скопление обрушившейся породы в стволе скважины затрудняет процесс промывки скважины, способствует посадке бурового инструмента и может стать причиной возникновения прихвата. Приведен анализ проблем бурения в трещиноватых аргиллитах, показаны механизмы, влияющие на стабильность открытого ствола скважины в отложениях трещиноватых аргиллитов. Для повышения стабильности аргиллитов, слагающих стенки ствола скважины, рекомендуется применение хлористого калия. Результаты подтверждаются данными экспериментальных исследований, проведенными по методике Ченеверта, а также тестирования на расклинивание трещин. При помещении образца аргиллита в раствор хлористого калия $(\mathrm{KCl})$ наблюдалось незначительное расширение и распространение на всю длину образца трещин, что является положительным результатом. Для повышения стабильности ствола скважины предлагаются пути дальнейшего изучения: повышение качества промывочного раствора путем ввода комплексных ингибирующих добавок, таких, например, как растворы солей в сочетании с высокомолекулярными полимерными композициями.

pus: 57191341737) - PhD in Engineering, Associate Professor at the Well Drilling Department (tel.: +0079650149785, Mariia V. Nutskova (Author ID in Scopus: 57191341737) - PhD in Engineering, Associate Professor

e-mail: Nutskova_MV@pers.spmi.ru, turitsyna_maria@mail.ru). The contact person for correspondence.
Inna V. Chudinova (Author ID in Scopus: 57196440179) - PhD in Engineering, Assistant at the Well Drilling Department (tel.: +007 91108652 29, e-mail: chudinova_iv@pers.spmi.ru).

Aleksandr N. Sobolev - Master's student at the Well Drilling Department (tel.: +007 98175156 39, e-mail: san9995@mail.ru).

Нуцкова Мария Владимировна - кандидат технических наук, доцент кафедры бурения скважин (тел.: + 00796501497 85, e-mail: Nutskova_MV@pers.spmi.ru). Контактное лицо для переписки.

Чудинова Инна Владимировна - кандидат технических наук, ассистент кафедры бурения скважин (тел.: + 00791108652 29, e-mail: chudinova_iv@pers.spmi.ru). Соболев Александр Николаевич - магистрант кафедры бурения скважин (тел.: + 00798175156 39, e-mail: san9995@mail.ru). 


\section{Introduction}

The recent international practice has proven that almost all wells are complicated by the process-related incompatibility of individual drilling intervals. Therefore, in most cases, multistring structures and drilling fluids with different technological properties are used. However, even advanced well design and construction technologies cannot solve all the drilling problems that obstruct fast and efficient drilling operations.

Maintaining the gauge hole, which depends on the wall stability, is one of the most challenging tasks when drilling oil and gas wells. Generally, this problem occurs when drilling through lowcohesion lithified sediments represented by argillite, clayey shales and shaly claystones. In their turn, argillite account for approximately $70 \%$ of all wellbore instability-related problems [1-13].

The problem of the borehole wall instability when drilling through mudrocks is widely described in various literature sources, and a range of solution options, which use involving, inhibiting and non-dispersion drilling fluids is provided [2, 3, 10-12, 14-27].

That being said, the issue of fractured argillite instability is not covered. Mainly, possible causes of fractured argillite destabilisation and control measures are described. However, there is no clear insight into reasons of loosing fractured argillite stability and solutions thereto, accordingly [7-9, 28-32].

In case of lost stability of the rocks forming the borehole walls, the major complications arise during drilling. There are different types of borehole wall stability failures, yet all of them are determined by changes in the gauge hole size. The hole enlarges with cavings caused by falling or sloughing rocks, and reduces with rock bulging that can incite both rock slides (rocks falling under gravity towards a well bottom) and bridging (rocks flowing from a well bottom to a well head).

Combating complications that cause gauge hole deviations is crucial when drilling relatively deep wells.

Many engineers and researchers believe that if the drilling fluid density is compatible with the geological and technical conditions, then the loss of borehole wall stability depends on the fluid physical and chemical effect on shale deposits being drilled into. As such, the studies are mainly focused on designing fluid compositions and parameters.
At present, there is a wide range of instrumental procedures for mudrock testing and studying to select a compatible drilling fluid. Most laboratory studies require expensive equipment [33]. Moreover, when constructing wells under difficult geological and technical conditions, many oil and gas companies conduct more detailed studies of shale deposits, including analyses of chemical and mineralogical compositions, losses on ignition, moisture content, density and exchange capacity. These studies are mainly focused on the interaction of mudrock samples with a drilling fluid; the tests for hydration, swelling-induced softening, dispersion, capillary imbibition, osmosis, etc. are conducted. The testing methods are specified in detail in the specialist literature [34].

Many experts believe that the drilling fluid that will ensure the maximum borehole wall stability has to be selected individually for each operation area and geological and technical conditions.

To select the best suited composition and properties of the drilling fluid, it is recommended to perform the following laboratory tests with unstable mudrock samples: X-ray diffraction analysis of rock mineralogical composition using a diffractometer, measurement of cation exchange capacity and detection of reacting cations, building of adsorption isotherms by the Chenevert method, and assessment of dispersion ability [35]. Despite the advanced research and testing methods, the problem of the mudrock stability loss on the borehole walls is yet pending solution, while the effectiveness of the proposed solutions is very low, with split opinions of researchers on this issue.

V.S. Baranov believes that increasing the drilling mud density will not inhibit mudrock caving, while the fluid loss control cannot ensure the borehole wall stability [35]. According to V.D. Gorodnov, the values of drilling fluid loss indicator and mudrock water content under conditions of natural occurrence strongly affect the wellbore stability in shale deposits. Moisture is an essential factor affecting the stability of borehole walls, since low-moisture mudrock tends to lose stability in moisture medium faster than its less moist varieties. V.D. Gorodnov divides mudrock into three classes depending on the change in strength properties subject to moisture degree: highly moistured (high-plasticity, flow rock), moistured (plastic rock) and low-moistured (hydration-active rock) [36]. 
V.A. Priklonsky states that stability can be estimated by a certain critical moisture content characteristic of each type of claystone. When the moisture content of a claystone sample falls below the critical level, the sample is slaking. If the moisture content exceeds the critical level, there is little to no slaking. The increase in the critical moisture content in claystones is directly proportional to the increase in their exchange capacity: for montmorillonite clay, the critical humidity level is about $50 \%$, and about $25 \%$ for kaolinite clay (37).

According to works of some researchers, the mudrock instability is mainly induced by the joint effect of such factors as the physical and chemical effects of drilling fluid filtrate and the stress state of rocks on borehole walls [38-40].

O.K. Angelopulo believes that it is necessary to set a lower limit of organic agent concentrations for a given filtrate loss value, at which the inhibiting effect is most pronounced [41]. In the analysis of field materials, N.M. Sherstnyov determined that the rock sloughing and falling under continuous exposure to drilling fluid occur in claystone deposits susceptible to tectonic faulting with a steep formation dip [42]. V.S. Voytenko believes that the drilling fluid weight shall be regulated as per claystone pore pressure [43]. A.I. Penkov, at the studies of the water absorption rate in claystone, highlights the advantages of the combined application of acrylic polymers and potassium chloride in drilling muds [44]. This technical solution has proved effective in the Western Siberian fields, yet of no effect in other fields.

In his monograph, V.S. Novikov states that the use of drilling fluids containing claystone swelling inhibitors does not solve the problem of unstable wellbore walls at intervals of argillite deposits [45]. Thus, the method of increasing the mud weight with the minimum filtrate loss rates did not help to slow down the rate of caving formation, while the application of oil-based muds could not fully prevent complications and sticking.

In his studies, V.S. Novikov states that most of the agents used in drilling accelerate the loss of borehole wall stability in claystone and serve to slow down this process only when combined with other agents. The combination of polyacrylamide and potassium chloride ensures the wellbore stabilisation.

M.R. Mavlyutov and N.I. Krysin recommend the use of drilling fluids that include potassium chloride and polyacrylamide [46]. The drilling fluids used by N.I. Krysin at claystone occurrence intervals in Perm Krai have proved to be most effective.

During the well drilling through mudrock in the Achimovian deposits of the Urengoy gas condensate field, V.V. Ippolitov et al. [47] have found that at deviation angles from 42 to $72^{\circ}$, the borehole wall sloughing progresses over time. The borehole wall disintegration rate, when drilling through such shales, may be 2-3 times higher compared to other shale deposits. The borehole walls disintegrate several times more when drilling with polymer drilling fluid with a content of solids of up to 5-7 \% compared to drilling with mud-laden fluids containing 20-30 \% of the detrital mudrock fraction being drilled out. When the drilling mud weight decreases from 1,190 to $1,100 \mathrm{~kg} / \mathrm{m}^{3}$, the rate of cavings increases by $1.4-$ 1.5 times. When drilling with polymer-mud fluids with a fluid loss rate of $6 \mathrm{~cm}^{3} / 30 \mathrm{~min}$, the rate of wellbore destabilisation is 20 times higher than that with a fluid loss rate of $2 \mathrm{~cm}^{3} / 30 \mathrm{~min}$. The use of potassium-based mud by Baroid DF specialists did not prove successful. At the same time, about $49 \%$ of the total well construction time was spent on eliminating complications related to instability of borehole walls. However, this approach would have been sufficiently effective in most parts of Western Siberia.

V.V. Ippolitov recommends using emulsion polymer-mud drilling fluids for drilling through fractured argillites.

L.K. Mukhin in his work suggests to switch to the use of hydrocarbon-based drilling fluids [48]. However, based on the practice, the use of hydrocarbon-based fluids at drilling intervals of unstable shale deposits does not always preclude complications. I.G. Yusupov together with experts of OAO TATNEFT have rationalized the mudrock instability in the fields of Tatarstan using the osmosis theory [49-51]. In his works, S.M. Gamzatov have studied the osmosis effect on the process of borehole wall stability loss in shale deposits [52].

S.V. Vasilchenko, A.G. Potapov and A.N. Gnoyevykh state that in the clay mineral lattice, explosive disturbances may arise resulting from the sharp change in iron ionic radius (transition from the divalent to trivalent state), which results in the wellbore stability loss [33]. When individual mudrock samples were placed in deionised water, it was found 
that some of the samples disintegrated without swelling. This fact has brought to the conclusion that it is essential to study comprehensively the physical characteristic of shales that determines its propensity to destabilisation when interacting with drilling fluids.

Since the geological and technical conditions of mudrock formation and occurrence vary from case to case, different solutions shall be applied to the issues related to borehole wall stabilisation. It should be noted that the effectiveness of these approaches that are associated with the use of new inhibiting drilling fluids, has not detected any noticeable advantages over existing ones. Moreover, using a new recommended mud often increased losses of mudrock borehole wall stability [52].

A possible reason for the lack of effectiveness in solving the problems with mudrock borehole wall stabilisation using recommended drilling fluids may be the errors made by researchers during laboratory studies and field tests. These errors are mainly caused by an attempt to simplify or speed up experiments or to disregard properties. Laboratory tests are carried out mainly with true shale or with mudrock samples, but, in any case, once the natural structural bonds are broken down, the selected samples are dried and dispersed to a powder state. When placed in identical test liquids, the samples with natural structural bonds and those compression-molded, display entirely different results: the sample with natural bonds remains stable for 30 days in aqueous medium with no signs of softening (Fig. 1, c), while the compression-molded sample (Fig. 1, a) in the same liquid turns into a powder after 5 minutes (Fig. 1, b). In such case, highly stable mudrocks may be mistaken for potentially unstable rocks.

Mudrock swelling is also studied after the sample is dried, dispersed and molded, with liquid interaction from all sides, yet the rocks on the wellbore walls are only moistened by drilling fluids from one side, while on the other three sides the nearwellbore rock is affected by overlying, underlying and lateral rocks. Figure 2 shows visual results of the study of all-sided and one-sided water-base fluid interaction with montmorillonite clay samples. It was visually determined that the rate of sample disintegration and swelling in the container is much higher than that of the compression-molded sample. It can be concluded that, due to incorrect studies, the recommended drilling fluids for maintaining the borehole wall stability in mudrocks have little to no effectiveness.
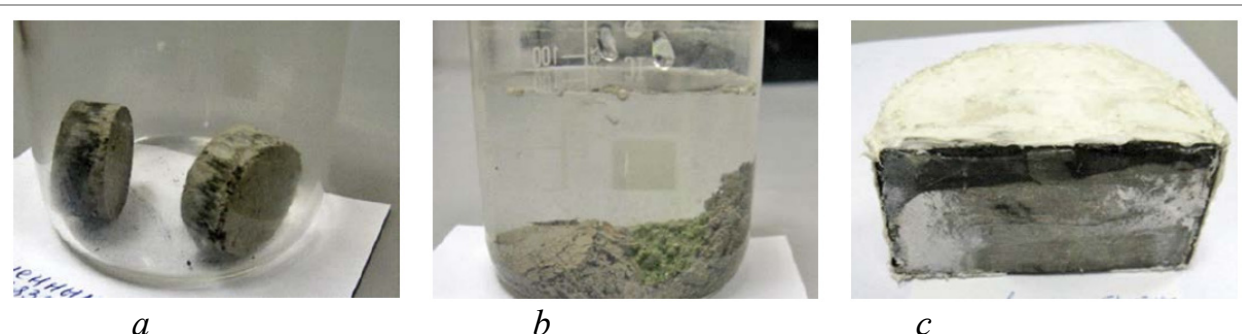

Fig. 1. Laboratory stability study of siltstone in aqueous medium with natural and artificial structural bonds: $a$-compression-molded sample; $b$ - sample with artificial structural bonds placed in aqueous medium; $c$ - sample with natural structural bonds
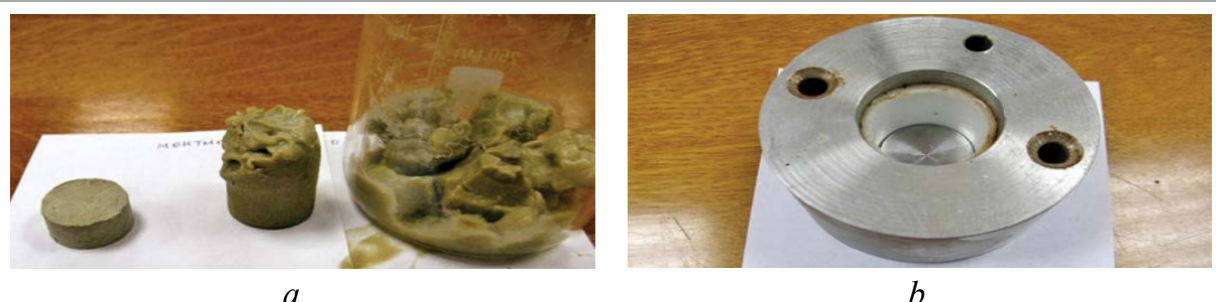

Fig. 2. Behaviour study of montmorillonite clay samples at all-sided and one-sided water saturation: $a$ - from left to right: compression-molded sample before the test; compression-molded sample after the test, placed in a cell and kept in aqueous medium; compression-molded sample after the test, placed in a glass and kept in aqueous medium; $b$ - a cell for compression-molded sample 
The studies in Russia and overseas are focused on swelling mudrocks. Many researchers are trying to address the issue of borehole wall instability when drilling through the deposits of shale, argillite and siltstone deposits by transferring the test results obtained with claystones. This idea being incorrect, it entails serious consequences when it comes to field practice, since the claystones, in turn, bear no resemblance to consolidated lithified mudrocks in terms of strength and deformation characteristics. It is known that the inhibitive muds that are effective in drilling plastic clays, are little to no effective in brittle fractured argillaceous rocks $[53,54]$.

The selection of the composition, properties and technological parameters of a drilling fluid that can successfully maintain the borehole wall stability must be based on the nature of mudrock deformation and disintegration, since it depends on the structure, strength and properties of structural bonds in the rock. Unfortunately, many experts underestimate or simply disregard the impact of this nature of stability loss. It is intended to classify mudrocks by the nature of their disintegration, which is reasonable.

By the strength of the structural bonds that determine stability, mudrocks are divided into rocky, semi-rocky and dispersed rocks. The first two types are characterized by rigid chemical structural bonds with cohesive contacts (found in shale). Mudrocks of the third type have physical, chemical, mechanical, water-colloid structural bonds with coagulation or transition contacts (found in claystones) [52].

The behaviour of externally-affected mudrocks in downhole conditions is driven by composition, structure and strength of structural bonds. There are mechanical models that describe mudrocks by the character of their deformation and disintegration: rocky metamorphic shales, semi-rocky sedimentary argillites and siltstones correspond to the elastoplastic model (brittle disintegration character), while dispersed cohesive sedimentary claystones and their varieties correspond to the plastic model (plastic or viscoplastic disintegration character). The claystones are capable of absorbing and retaining water in bound state; therefore, the claystones on the borehole walls are further plasticised, start flowing, swelling, narrow the gauge hole and collapse down the well. Argillites are not plasticised when exposed to drilling fluids, always remain brittle and do not swell (54). Argillites are destabilised and slough down the well due to fractures: mud filtrate and/or mud itself invades and props microfractures, while the rock particles disintegrate and slough. When mudrocks are classified into plastic claystones and brittle shales (or argillites) by the nature of their disintegration, the mitigation of borehole instability problems by choosing the drilling fluid becomes considerably simpler and easier.

Sloughing of potentially unstable shales at well drilling is largely prevented by increasing the mud weight and inhibiting properties. The increased mud weight affects maintaining the wellbore stability both positively and negatively. A similar result can be achieved with the increase of the mud's inhibiting properties.

Electrolytes, such as sodium, potassium, magnesium, calcium chlorides and others, are used for the drilling mud inhibition, some of them having an ordering effect on water molecules. That is, the water molecule is structured, while the water phase viscosity increases. The rest of the electrolytes provide a destructive effect on the associated water molecules and destroy the system, while the water phase viscosity decreases.

The ongoing likelihood of unstable shale fracturing and sloughing can be reduced by using solid bridging agents of different sizes and natures (hydrophobic, hydrophilic) and hydrophobic liquid bridging agents of different molecular mass and structure. Therefore, to reduce the fracture propping effect, the conventional freshwater solutions or saltwater solutions that structure water molecules containing solid (hydrophobic, hydrophilic) and liquid hydrophobic bridging agents are used. The bridging agent principle is to form a blocking layer to prevent the drilling fluid liquid phase from invading into the fractures, and to bind the shale particles split along the fractures using adhesive forces.

An increase in the concentration of bridging agents (liquid and solid, hydrophobic and hydrophilic) in the drilling fluid increases fracture sealing off and maintains the wellbore stability when drilling through unstable shales.

Maintaining a drilling mode that will eliminate severe dog leg when drilling through shale deposits should be ensured, as well. High mud annular velocity combined with low structural and rheological indicators at drilling create a turbulent flow of the drilling fluid, which induces wellbore shale instability and sloughing. 
Therewith, to reduce the turbulent flow impact on borehole walls, the pump rate can be reduced, or it would make more sense to adjust the mud rheological properties, which in turn boosts its lifting capacity and the transition to laminar (plug) flow mode. Pressure pulse in a wellbore while tripping may negatively impact the shale stability, and, accordingly, the speed of pipe running in and out should be minimised.

Thus, drilling through the areas of potentially unstable shales requires the use of freshwater polymer drilling fluids or salt-base solutions that structure water molecules, with an increased concentration of solid and liquid adhesive hydrophobic bridging agents.

In this case, the structural and rheological properties of drilling fluids should be maintained at the highest possible level. Competent management of mud properties and operational parameters boosts technical and economic performance when drilling under conditions of possible borehole wall instability.

When plastic and brittle mudrocks alternate in a lithological section, a drilling fluid that can ensure the stability of both plastic claystones and brittle shales shall be used: a water-base drilling fluid that includes cationic polymers in its formulation, is most effective for such sections.

\section{Fractured Argillites Study Methodology}

Fracture propping by drilling fluid invasion and argillite swelling is a probable causative factor that destabilises highly-fractured argillites in borehole walls. Drilling fluid also invades nearwellbore zone or moves out under the variable hydrostatic pressure, associated with the circulating pressure increase and the buildup or loss of equivalent circulating density. In this way, the pressure front propagates deep into the nearwellbore zone of shale formations and causes complications through sloughing, sliding and caving.

To determine the drilling fluid impact on argillites, a range of laboratory studies have been proposed to analyse the processes in the sediments of highly-fractured argillites during drilling. A sample was cored at a depth of 1,385-1,475 m from the deposits pertaining to the Artinskian stage of the Permian system.

The argillite sample has a bedded texture that splits into layers along bedding planes (Fig. 3).

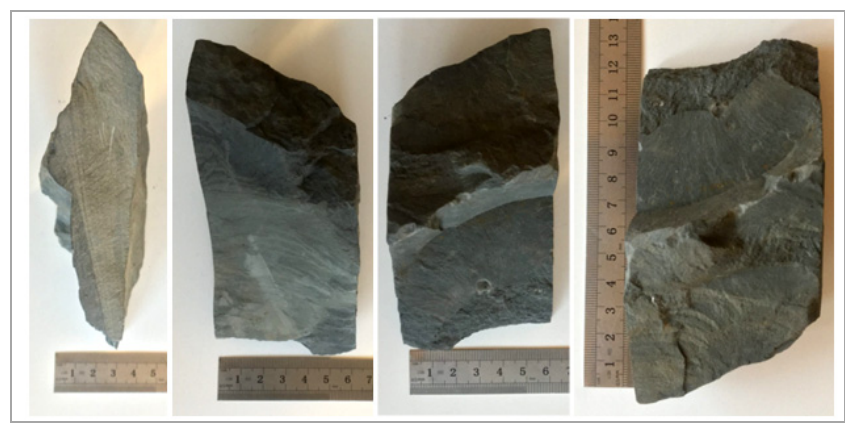

Fig. 3. Argillite sample

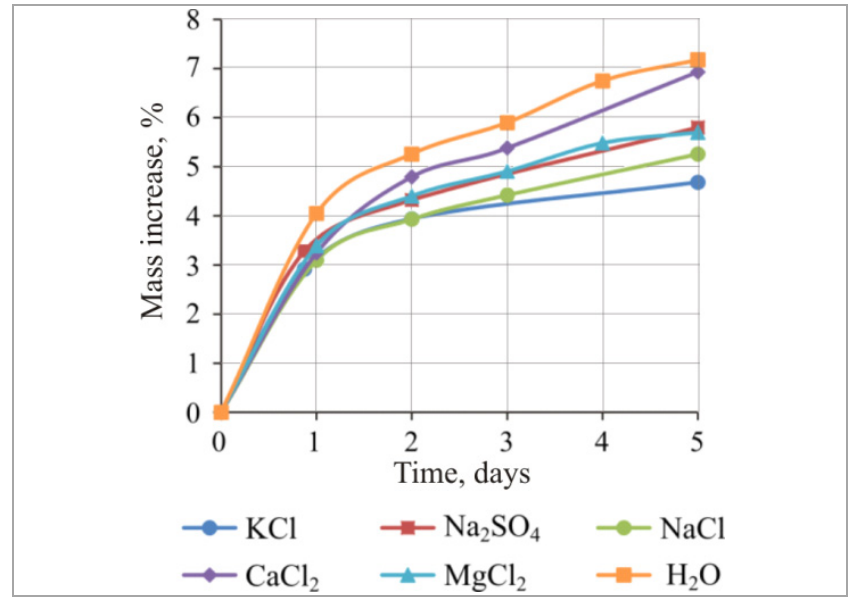

Fig. 4. Dynamics of sample mass percentage increase in vaporous media of saturated solutions

The study of fracturing at interaction with fluids may provide the maximum insight into the stability of shale deposits prone to fracturing when exposed to drilling muds.

The methodology is relatively simple, yet this doesn't negate the study's effectiveness: a rock sample of a near regular shape, with dimensions of $2 \times 3 \mathrm{~cm}$, is immersed into the liquid under test at room temperature. The study enables to assess the actual effect of the liquid on the mudrock in the absence of additional exposure to the samples (fluid flow, pressure, temperature and others). Fracturing in the samples is determined visually at set time intervals.

Six argillite samples were prepared for the test and placed in various fluids for 6 hours. The time interval was chosen in the course of the test (the time period after the lapse of which the argillite was fully softened). Pictures of the samples were taken at the start of the test, after 10 minutes and 6 hours later.

Practically, the drilling fluid formulation includes 3 to $7 \%$ of sodium chloride $(\mathrm{NaCl})$ and $5 \%$ to $20 \%$ of potassium chloride $(\mathrm{KCl})$ to inhibit or prevent cleaving of the drilled rock and maintain borehole wall stability. 
The use of sodium salts ensures moderate to strong inhibition, while potassium salts induce strong inhibition. Sodium and potassium chloride solutions were proposed as the fracturing test base. The study was also conducted in $5 \%$ solutions of $\mathrm{Na}_{2}(\mathrm{SO})_{4}, \mathrm{CaCl}_{2}, \mathrm{MgCl}_{2}$ and pure water.

The Chenevert method allows to evaluate the adsorption forces for various inhibitive compounds. The test procedure consists in placing dried particles of argillite cuttings in a dessicator containing saturated solutions of various salts. Then, water content is determined by the change in the sample mass after certain time intervals, and the dependencies of water content on relative humidity are built [55].

The fluid activity in argillites is determined by the abscissa of isotherm point with the ordinate equal to the argillite humidity value under formation conditions. This parameter can be used to define a potential swelling pressure of fractured argillite that absorbs water from drilling fluid. The lower the water activity under formation conditions, the higher the maximum possible swelling pressure [55].
X-ray crystallography using a diffractometer is mainly used to determine the mineralogical composition of argillite. This method consists in the X-ray diffraction on a space crystal lattice.

The argillite sample was cored at the Labaganskoye field in the Nenets Autonomous District. In the north-east of the area, the mineral composition of argillite is virtually identical and mainly includes illite and kaolinite, only the percentage ratios varying subject to its formation conditions. Following the diffractometer analysis data, the fractured argillites are mainly composed of kaolinite (47-78\%), illite (10-30\%) and authigenic chlorite (3-18\%) [56]. The argillite sample contains a high proportion of kaolinite, which signifies the low cation exchange capacity, swelling ability and water retentivity properties.

\section{Laboratory Results}

Figure 4 shows data on mass change of argillite samples in a vaporous medium of saturated $5 \%$ solutions of $\mathrm{KCl}, \mathrm{Na}_{2}(\mathrm{SO})_{4}, \mathrm{NaCl}$, $\mathrm{CaCl}_{2}, \mathrm{MgCl}_{2}$ and water.

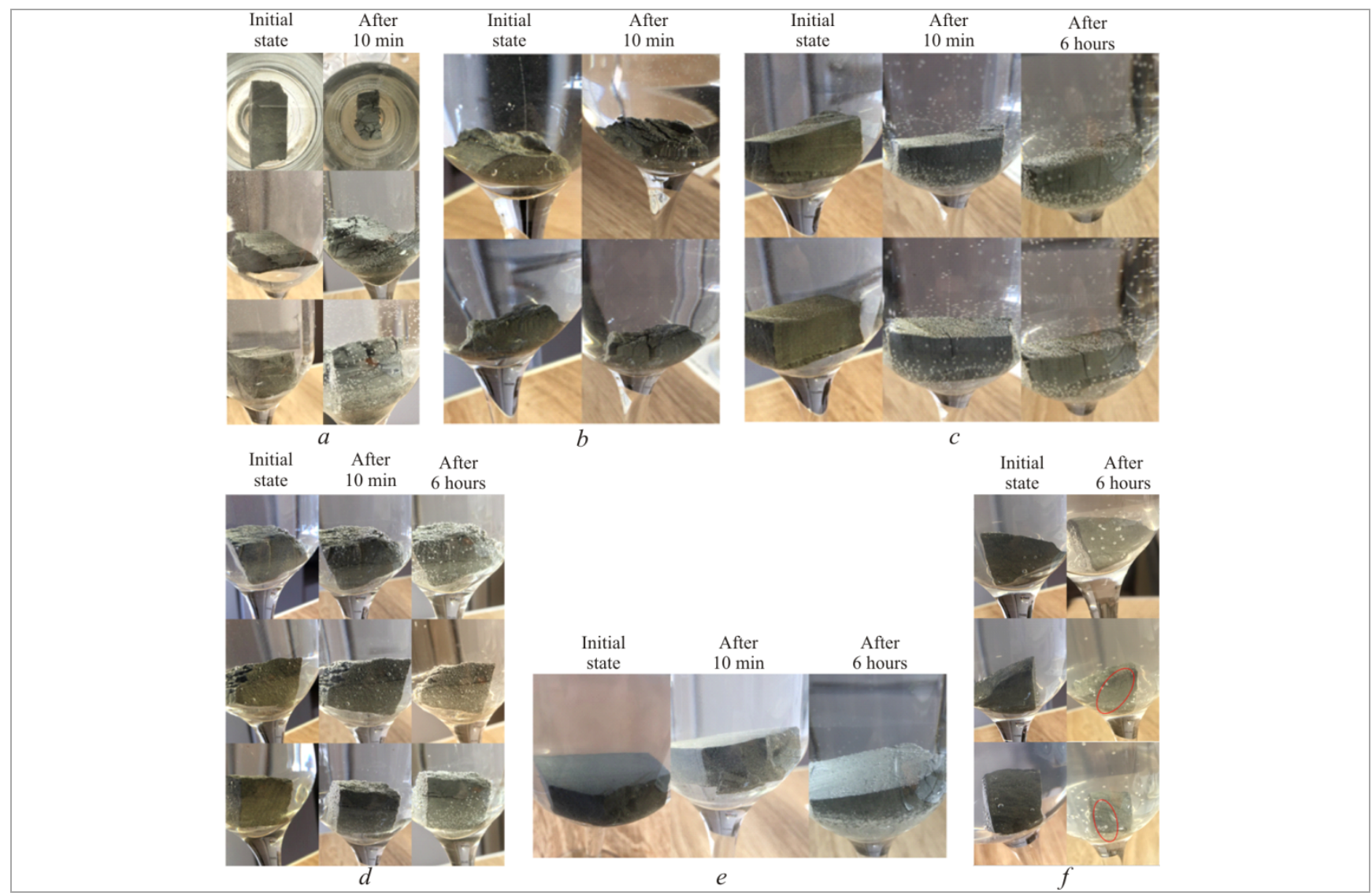

Fig. 5. Argillite sample at interaction with: $a$ - water at the start of the test and after $10 \mathrm{~min} ; b-\mathrm{NaCl}$ at the start of the test and after $10 \mathrm{~min} ; c-\mathrm{Na}_{2} \mathrm{SO}_{4}$ at the start of the test, after $10 \mathrm{~min}$ and after 6 hours, respectively; $d-\mathrm{MgCl}_{2}$ at the start of the test and after 6 hours; $e-\mathrm{CaCl}_{2}$ at the start of the test and after 6 hours; $f-\mathrm{KCl}$ at the start of the test and after 10 min 
The minimum increase in the sample mass was observed in the vapours of $\mathrm{KCl}$ saturated solution. The most mass increase occurs after the first day of the sample exposure to the solutions vapours, and after the fifth day the mass increase is insignificant, so the recommend test duration is 5 days.

The fracturing test revealed that the effect of water as a reference parameter significantly increases the existing fractures in the argillite sample (Fig. 5, a). After 10 minutes of interaction, a complete rock softening is observed, and the sample interaction with a $5 \% \mathrm{NaCl}$ solution yielded the same result (Fig. 5, b). When argillite interacts with $5 \%$ solutions of $\mathrm{MgCl}_{2}, \mathrm{Na}_{2} \mathrm{SO}_{4}$ and $\mathrm{CaCl}_{2}$, the formation and expansion of fractures along bedding planes with simultaneous rock disintegration is observed over time (after 6 hours) (Fig. 5, c-e). When the argillite sample was placed in a $5 \%$ potassium chloride $(\mathrm{KCl})$ solution, minor expansion and propagation of fractures was observed along the entire sample length, which is a positive result (Fig. 5, f).

Following the study results, the following conclusions can be drawn: the interaction of water with the fractured argillite has a negative impact on its stability; potassium chloride solution provides more stability to the fractured argillites of the Labaganskoye field; the results with potassium chloride using the Chenevert method and the fracturing test are identical.

\section{Conclusions}

Following the study of a fractured argillite sample cored at a depth of 1,385-1,475 m from the deposits pertaining to the Artinskian stage of the Permian system, it was proved that the argillite interaction with the drilling fluid is the primary causative factor leading to its instability.

The Chenevert method was used to determine the swelling potential of argillite samples. The fracturing test clearly demonstrated the drilling fluid ability to prop existing fractures. Potassium chloride salt solution ( $\mathrm{KCl})$ ensures greater stability of argillite, which is confirmed by the study involving two test methods.

\section{References}

1. Blinov P.A. Opredelenie ustoichivosti stenok skvazhiny pri prokhodke intervalov slabosviazannykh gornykh porod s uchetom zenitnogo ugla [Determining the stability of the borehole walls at drilling intervals of loosely coupled rocks considering zenith angle]. Zapiski Gomogo instituta, 2019, vol. 236, pp. 172-179. DOI: 10.31897/PMI.2019.2.172
2. Nekrasova I.L., Khvoshchin P.A., Kazakov D.A. et al. Kompleks metodov otsenki ingibiruiushchikh svoistv burovykh rastvorov po otnosheniiu $\mathrm{k}$ glinistym nabukhaiushchim gornym porodam (na primere "reaktivnykh" glin montmorillonitovoi gruppy kazanskogo, tatarskogo iarusov permskoi sistemy) [Complex of methods to evaluate inhibiting properties of muds in relation to clay swelling rocks (at example of "reactive" clays of montmorillonite group of Kazanian, Tatarian ages in Permian system)]. Vestnik Permskogo natsionalnogo issledovatel'skogo politekhnicheskogo universiteta. Geologiia. Neftegazovoe i gornoe delo, 2019, vol. 19, no. 2, pp. 150-161. DOI: 10.15593/2224-9923/2019.2.5

3. Zakharov M.A., Karipova N.A. Opytno-promyslovaia rabota pri burenii zon nestabil'nykh argillitov s primeneniem sistemy PER-FLEX na Suzunskom mestorozhdenii [Pilot field work while drilling zones of unstable mudstones using the PER-FLEX system at the Suzunskoye field]. Nauchnyi zhurnal, 2018, no. 3 (26), pp. 14-18.

4. Lu Y.H. et al. Experimental study of strength properties of deep mudstone under drilling fluid soaking. Chinese Journal of rock mechanics and engineering, 2012, vol. 31, no. 7, pp. 1399-1405.

5. Corkum A.G., Martin C.D. The mechanical behaviour of weak mudstone (Opalinus Clay) at low stresses. International Journal of Rock Mechanics and Mining Sciences, 2007, vol. 44, no. 2, pp. 196-209. DOI: 10.1016/j.ijrmms.2006.06.004

6. Yan X.Z., Yang H.L., Yang X.J. The reason analysis of mudstone creep on casing damage. Drilling \& Production Technology, 2003, vol. 26, no. 3, pp. 65-69.

7. Guo J. et al. Apparent overconsolidation of mudstones in the Kumano Basin of southwest Japan: Implications for fluid pressure and fluid flow within a forearc setting. Geochemistry, Geophysics, Geosystems, 2013, vol. 14, no. 4, pp. 1023-1038. DOI: 10.1002/ggge.20042

8. Eseme E., Littke R., Krooss B.M. Factors controlling the thermo-mechanical deformation of oil shales: Implications for compaction of mudstones and exploitation. Marine and petroleum geology, 2006, vol. 23, no. 7, pp. 715-734. DOI: $10.1016 /$ j.marpetgeo.2006.02.007

9. Mondol N.H. et al. Experimental mechanical compaction of clay mineral aggregates - Changes in physical properties of mudstones during burial. Marine and Petroleum Geology, 2007, vol. 24, no. 5, pp. 289-311. DOI: $10.1016 /$ j.marpetgeo.2007.03.006

10. Moradi S.S.T., Nikolaev N.I., Chudinova I.V. Geomechanical analysis of Wellbore stability in high-pressure, hightemperature formations. 79th EAGE Conference and Exhibition 2017. European Association of Geoscientists \& Engineers, 2017, vol. 2017, no. 1 , pp. 1-3. DOI: $10.3997 / 2214-4609.201701463$

11. Moradi S.S.T. et al. Geomechanical study of well stability in high-pressure, high-temperature conditions. Geomechanics and Engineering, 2018, vol. 16, no. 3, pp. 331-339. DOI: $10.12989 /$ gae.2018.16.3.331

12. Moradi S.S.T., Nikolaev N., Khormali A. A Comprehensive Uncertainty Assessment of Wellbore Stability Models. Saint Petersburg 2018. European Association of Geoscientists \& Engineers, 2018, vol. 2018 , no. 1 , pp. 1-5. DOI: $10.3997 / 2214-4609.201800114$

13. Prischepa O. et al. Assessment of petroleum exploration activity performed in the timan-pechora petroleum province. Saint Petersburg 2018. European Association of Geoscientists \& Engineers, 2018, vol. 2018, no. 1, pp. 1-5. DOI: 10.3997/2214-4609.201800159

14. Nekrasova I.L. Sovershenstvovanie kriteriev otsenki kachestva burovykh rastvorov na uglevodorodnoi osnove v zavisimosti ot gorno-geologicheskikh uslovii ikh primeneniia [Improvement of the criteria for assessing the quality of hydrocarbonbased muds in terms of geological conditions of their use]. Vestnik Permskogo natsional'nogo issledovatel'skogo politekhnicheskogo universiteta. Geologiia. Neftegazovoe i gornoe delo, 2018, vol. 18, no. 2 , pp. 129-139. DOI: 10.15593/2224-9923/2018.4.3

15. Nekrasova I.L. Aspekty ekologicheskoi i promyshlennoi bezopasnosti primeneniia tekhnologicheskikh zhidkostei na nevodnoi osnove $\mathrm{v}$ protsessakh stroitel'stva i osvoeniia skvazhin [Aspects of environmental and industrial safety of non-aqueous process fluids in construction and completion of wells]. Vestnik Permskogo natsional'nogo issledovatel'skogo 
politekhnicheskogo universiteta. Geologiia. Neftegazovoe i gornoe delo, 2018, vol. 18, no. 1, pp. 41-52. DOI: 10.15593/2224-9923/2018.3.4

16. Babushkin E.V., Buianova M.G., Agliullin A.Kh., Konesev G.V., Teptereva G.A. Razrabotka ingibiruiushchikh burovykh rastvorov dlia povysheniia effektivnosti stroitel'stva skvazhin $\mathrm{v}$ slozhnykh gornogeologicheskikh usloviiakh [Development of inhibiting drilling solutions for increasing efficiency of well construction in complex mining-geological conditions]. Nanotekhnologii $v$ stroitel'stve: nauchnyi internet-zhumal, 2018, vol. 10, no. 2, pp. 42-62. DOI: 10.15828/2075-8545-2018-10-2-42-62

17. Kulyshev Iu.A., Gadiiatov E.V., Ulianova Z.V., Boiarintseva M.N. $\mathrm{O}$ rezultatakh primeneniia kationnogo burovogo rastvora ULTRASAFE STAB $+[$ Regarding the results of the application of the cationic drilling mud «ULTRASAFE STAB + »]. Burenie i neft', 2018, no. 11, pp. 44-47.

18. Chetvertneva I.A., Belenko E.V., Gaisin I.F., Teptereva G.A., Shavshukova S.Iu. Otsenka effektivnosti primeneniia emul'sionnogo burovogo rastvora pri razburivanii glinisto-argillitovykh porod volgoural'skogo regiona [Evaluation of emulsion drilling fluid when drilling on clay-argillitovyh rocks of the Volga-Ural region]. Transport $i$ khranenie nefteproduktov $i$ uglevodorodnogo syria, 2019, no. 1, pp. 34-37. DOI:10.24411/0131-4270-2019-10107

19. Nekrasova I.L., Khvoshchin P.A., Garshina O.V., Konesev G.V. Novye podkhody $\mathrm{k}$ otsenke ingibiruiushchikh svoistv invertno-emul'sionnykh burovykh rastvorov [New approaches to inhibitory properties evaluation of invert emulsion drilling fluids]. Stroitel'stvo neftianykh i gazovykh skvazhin na sushe i na more, 2017, no. 2, pp. 28-34.

20. Zhaohui S. Application of Drilling Fluids of Saturated Composite Salt Water in Well Li97 [J]. Sino-Global Energy, 2011, vol. 2.

21. Li G. et al. Nanotechnology to improve sealing ability of drilling fluids for shale with micro-cracks during drilling. SPE international oilfield nanotechnology conference and exhibition. Society of Petroleum Engineers, 2012. DOI: 10.2118/156997-MS

22. Huang W.L. et al. New Strong Inhibitory Polyamine Drilling Fluid System Research in Yubei Area. Advanced Materials Research. Trans Tech Publications Ltd, 2013, vol. 807, pp. 2519-2522. DOI: 10.4028/www.scientific.net/AMR.807-809.2519

23. Minghua L. et al. Application of Oil-based Drilling Fluid in Unconventional Oil-gas Reservoirs, Zhongyuan Oilfield [J]. Sino-Global Energy, 2013, vol. 7.

24. Chao M. et al. Application of anti-collapse aluminum matrix drilling fluid system in Jilin oilfield. ICPTT 2012: Better Pipeline Infrastructure for a Better Life, 2013, pp. 196-208. DOI: $10.1061 / 9780784412619.023$

25. Calvin Lowrans C.L. Optimising drilling fluid to maintain mudstone formation stability, 2012, $34 \mathrm{p}$.

26. Nutskova M.V. et al. Research of oil-based drilling fluids to improve the quality of wells completion. IOP Conference Series: Materials Science and Engineering. IOP Publishing, 2019, vol. 666, no. 1, pp. 012065. DOI: 10.1088/1757-899X/666/1/012065

27. Podoprigora D., Raupov I. Research of the influence of polymeric drilling mud on the filtration-capacitive properties of polymictic sandstones. Acta Technica CSAV (Ceskoslovensk Akademie Ved), 2018, vol. 63, no. 4, pp. 537-546.

28. Kapitonov V.A., Fedosenko O.V., Iurchenko V.V. Rassmotrenie faktorov, vliiaiushchikh na ustoichivost' argillitov [Considering the factors that affect the stability of argillites]. Neft' Gaz. Novatsii, 2017, no. 10, pp. 22-25.

29. Aliev A.F., Agzamov F.A. Analiz protsessa bureniia skvazhiny pod tekhnicheskuiu kolonnu na mestorozhdeniiakh imeni R. Trebsa i A. Titova [Analysis of a well drilling process for a technical casing string in the fields named after R. Trebs and A. Titov]. Stroitel'stvo neftianykh i gazovykh skvazhin na sushe i na more, 2018, no. 9, pp. 9-14. DOI: 10.17122/ntj-oil-2017-4-52-62

30. Chetvertneva I.A., Belenko E.V., Gaisin I.F. Osobennosti bureniia glinisto-argillitovykh porod volgo-ural'skogo regiona [Features of drilling in shale and argillite formations of the VolgaUrals oil province]. Neft'. Gaz. Novatsii, 2019, no. 6, pp. 49-52.

31. Shirokov M.N. Iskliuchitel'naia stabil'nost' stvola skvazhiny: chto delat', kogda ne rabotaet povyshenie plotnosti burovogo rastvora? [Exceptional wellbore stability: what to do when drilling mud weighting does not work?]. Burenie $i$ neft', 2019, no. 9, pp. 46-49.

32. Santarelli F., Dardeau C., Zurdo C. Drilling through highly fractured formations: A problem, a Model, and s Cure. Journal of petroleum technology, 1992, no. 24592, $10 \mathrm{p}$.

33. Vasil'chenko S.V., Potapov A.G., Gnoevykh A.N. Sovremennye metody issledovaniia problemy neustoichivosti glinistykh porod pri stroitel'stve skvazhin [Modern methods of studying the problem of instability of clay rocks during well construction]. Moscow: IRTs Gazprom, 1998, 83 p.

34. Dir Z.U.A., Khaui R.A., Zusman D. Porodoobrazuiushchie mineraly [Rock-forming minerals]. Moscow: Mir, 1966, vol. 3, 318 p.

35. Baranov V.S. Glinistye rastvory dlia bureniia skvazhin v oslozhnennykh usloviiakh [Clay muds for drilling wells in difficult conditions]. Moscow: Gostopttekhizdat, 1955, 254 p.

36. Gorodnov V.D. Fiziko-khimicheskie metody preduprezhdeniia oslozhnenii $\mathrm{v}$ burenii [Physicochemical methods for preventing complications in drilling]. Moscow: Nedra, 1984, 229 p.

37. Priklonskii V.A. Gruntovedenie [Soil science]. Moscow: Gosgeolitizdat, 1949, vol. 1, 400 p.

38. Grei Dzh.R., Darli G.S. Sostav i svoistva burovykh agentov (promyvochnykh zhidkostei) [Composition and properties of drilling agents (flushing fluids)]. Moscow: Nedra, 1985, 509 p.

39. Kistre E.G. Khimicheskaia obrabotka burovykh rastvorov [Chemical treatment of drilling fluids]. Moscow: Nedra, 1972, $392 \mathrm{p}$.

40. Rzhevskii V.V., Novikov G.Ia. Osnovy fiziki gornykh porod [Fundamentals of Rock Physics]. Moscow: Nedra, 1973, 211 p.

41. Angelopulo O.K., Podgornov V.M., Avakov V.E. Burovye rastvory dlia oslozhnennykh uslovii [Drilling fluids for difficult conditions]. Moscow: Nedra, 1988, 135 p.

42. Sherstnev N.M., Rasizade Ia.M., Shirinzade S.Ia. Preduprezhdenie i likvidatsiia oslozhnenii v burenii [Prevention and elimination of complications in drilling]. Moscow: Nedra, 1979, $297 \mathrm{p}$.

43. Voitenko V.S. Upravlenie gornym davleniem pri burenii skvazhin [Rock pressure management while drilling wells]. Moscow: Nedra, 1985, 180 p.

44. Pen'kov A.I. Vliianie polimerov na ingibirovanie glin [Effect of polymers on clay inhibition]. Neftianoe khoziaistvo, 1979, no. 5 .

45. Novikov V.S. Ustoichivost' glinistykh porod pri burenii skvazhin [Stability of clay rocks when drilling wells]. Moscow: Nedra, 2000, 270 p.

46. Krysin N.I., Mavliutov M.R., Ishmukhametova A.M. et al. Primenenie bezglinistykh polimersolevykh rastvorov [Application of clay-free polymersaline solutions]. Perm', 1982, 64 p.

47. Ippolitov V.V., Sevodin N.M., Usynin A.F. Obespechenie ustoichivosi glinistykh porod pri burenii naklonno-napravlennykh skvazhin na mestorozhdeniiakh severnoi chasti Zapadnoi Sibiri [Ensuring the stability of clay rocks when drilling directional wells in the fields of the northern part of Western Siberia]. Vestnik Assotsiatsii burovykh podriadchikov, 2000, no. 2, pp. 13-18.

48. Mukhin L.K. Burovye rastvory na uglevodorodnoi osnove dlia bureniia $\mathrm{v}$ oslozhnennykh usloviiakh i vskrytiia produktivnykh plastov [Oil-based drilling fluids for drilling in challenging conditions and opening up productive formations]. Doctor's degree dissertation. Moscow: MINKh i GP, 1971, 148 p.

49. Bichkurin T.N., Iusupov I.G., Gabidullin R.S. et al. Issledovanie tekhniko-tekhnologicheskikh faktorov, opredeliaiushchikh ustoichivost' kynovskiikh argillitov pri burenii skvazhin [Study of technical and technological factors that determine the stability of the Kynovsky mudstones when drilling wells]. Neftianoe khoziaistvo, 2000, no. 12, pp. 25-27.

50. Takhautdinov Sh.F., Bikchurin T.N., Iusupov I.G. Issledovanie po razrabotke tekhnologii vskrytiia kynovskogo gorizonta pod bol'shim zenitnym uglom [Researches on development of technology of kynovskiy horizon strike under the large inclination angle]. Neftianoe khoziaistvo, 2003, no. 3, pp. 35-39.

51. Iusupov I.G. Fiziko-geologicheskie issledovaniia iavlenii obvaloobrazovaniia neustoichivykh gornykh porod pri burenii skvazhin i 
mery ikh predotvrashcheniia [Physico-geological studies of the phenomena of collapse of unstable rocks during well drilling and measures to prevent them]. Ph. D. thesis. Moscow: MINKh imeni Gubkina, 1966.

52. Gamzatov S.M. Vliianie osmoticheskogo iavleniia na kavernoobrazovaniia [Influence of the osmotic phenomenon on cavitation]. Burenie, 1974, no. 8, pp. 16-18.

53. Forsans T.M., Schmitt L. Capillary forces: the neglected factor in shale instability studies? In EUROCK'94. Balkema. Rotterdam, 1994, vol. 71. DOI: 10.2118/28029-MS

54. Cheng F.A., Lu A. New technique for evaluation of shale stability in the presentce of polymeric drilling fluid. SPE Production Engineering, 1988, vol. 3, no. 3, pp. 366-374. DOI: 10.2118/14249-PA

55. Chenevert M.E. Glycerol mud additive provides shale Stability. Oil and Gas J., YII. 87, no. 29, pp. 60, 61, 64.

56. Riabinkina N.N., Valiaeva O.V. Sostav i organicheskoe veshchestvo argillitov nizhnego karbona Pechorskogo basseina Neftegazovaia geologiia. Teoriia i praktika, 2017, vol. 12, no. 1, available at: www.ngtp.ru/ rub/1/2_2017.pdf (accessed 10 February 2020). DOI: $10.17353 / 2070-5379 / 22017$

\section{Библиографический список}

1. Блинов П.А. Определение устойчивости стенок скважины при проходке интервалов слабосвязанных горных пород с учетом зенитного угла // Записки Горного института. 2019. - T. 236. - C. 172-179. DOI: 10.31897/PMI.2019.2.172

2. Комплекс методов оценки ингибирующих свойств буровых растворов по отношению к глинистым набухающим горным породам (на примере «реактивных» глин монтмориллонитовой группы казанского, татарского ярусов пермской системы) / И.Л. Некрасова, П.А. Хвощин, Д.А Казаков [и др.] // Вестник Пермского национального исследовательского политехнического университета. Геология. Нефтегазовое и горное дело. - 2019. - Т. 19, № 2. C. $150-161$. DOI: $10.15593 / 2224-9923 / 2019.2 .5$

3. Захаров М.А., Карипова Н.А. Опытно-промысловая работа при бурении зон нестабильных аргиллитов с применением системы PER-FLEX на Сузунском месторождении // Научный журнал. - 2018. - № 3 (26). - С. 14-18.

4. Experimental study of strength properties of deep mudstone under drilling fluid soaking / Y.H. Lu [et al.] // Chinese Journal of rock mechanics and engineering. - 2012. - Vol. 31, № 7. - P. 1399-1405.

5. Corkum A.G., Martin C.D. The mechanical behaviour of weak mudstone (Opalinus Clay) at low stresses // International Journal of Rock Mechanics and Mining Sciences. - 2007. - Vol. 44, № 2. - C. 196-209. DOI: 10.1016/j.ijrmms.2006.06.004

6. Yan X.Z., Yang H.L., Yang X.J. The reason analysis of mudstone creep on casing damage // Drilling \& Production Technology. - 2003. - Vol. 26, № 3. - P. 65-69.

7. Apparent overconsolidation of mudstones in the Kumano Basin of southwest Japan: Implications for fluid pressure and fluid flow within a forearc setting / J. Guo [et al.] // Geochemistry, Geophysics, Geosystems. - 2013. - Vol. 14, № 4. - P. 1023-1038. DOI: $10.1002 /$ ggge.20042

8. Eseme E., Littke R., Krooss B.M. Factors controlling the thermo-mechanical deformation of oil shales: Implications for compaction of mudstones and exploitation // Marine and petroleum geology. - 2006. - Vol. 23, № 7. - P. 715-734. DOI: $10.1016 /$ j.marpetgeo.2006.02.007

9. Experimental mechanical compaction of clay mineral aggregates - Changes in physical properties of mudstones during burial / N.H. Mondol [et al.] // Marine and Petroleum Geology. - 2007. - Vol. 24, № 5. - P. 289-311. DOI: $10.1016 /$ j.marpetgeo.2007.03.006

10. Moradi S.S.T., Nikolaev N.I., Chudinova I.V. Geomechanical analysis of Wellbore stability in high-pressure, hightemperature formations // 79th EAGE Conference and Exhibition
2017. - European Association of Geoscientists \& Engineers, 2017. Vol. 2017, № 1. - P. 1-3. DOI: 10.3997/2214-4609.201701463

11. Geomechanical study of well stability in high-pressure, high-temperature conditions / S.S.T. Moradi [et al.] // Geomechanics and Engineering. - 2018. - Vol. 16, № 3. - P. 331-339. DOI: DOI: 10.12989/gae.2018.16.3.331

12. Moradi S.S.T., Nikolaev N., Khormali A. A Comprehensive Uncertainty Assessment of Wellbore Stability Models // European Association of Geoscientists \& Engineers, 2018. - Saint Petersburg, 2018. - Vol. 2018, № 1. - P. 1-5. DOI: 10.3997/2214-4609.201800114

13. Assessment of petroleum exploration activity performed in the timan-pechora petroleum province / O. Prischepa [et al.] // European Association of Geoscientists \& Engineers, 2018. - Saint Petersburg, 2018. - Vol. 2018, № 1. - P. 1-5. DOI: $10.3997 / 2214-4609.201800159$

14. Некрасова И.Л. Совершенствование критериев оценки качества буровых растворов на углеводородной основе в зависимости от горно-геологических условий их применения // Вестник Пермского национального исследовательского политехнического университета. Геология. Нефтегазовое и горное дело. - 2018. - Т. 18, № 2. С. 129-139. DOI: $10.15593 / 2224-9923 / 2018.4 .3$

15. Некрасова И.Л. Аспекты экологической и промышленной безопасности применения технологических жидкостей на неводной основе в процессах строительства и освоения скважин // Вестник Пермского национального исследовательского политехнического университета. Геология. Нефтегазовое и горное дело. - 2018. - Т. 18, № 1. - С. 41-52. DOI: $10.15593 / 2224-9923 / 2018.3 .4$

16. Разработка ингибирующих буровых растворов для повышения эффективности строительства скважин в сложных горно-геологических условиях / Э.В. Бабушкин, М.Г. Буянова, А.Х. Аглиуллин, Г.В. Конесев, Г.А. Тептерева // Нанотехнологии в строительстве: научный интернет-журнал. - 2018. - Т. 10, № 2. C. 42-62. DOI: 10.15828/2075-8545-2018-10-2-42-62

17. О результатах применения катионного бурового раствора ULTRASAFE STAB + / Ю.А. Кулышев, Е.В. Гадиятов, 3.В. Ульянова, М.Н. Бояринцева // Бурение и нефть. - 2018. № 11. - С. 44-47.

18. Оценка эффективности применения эмульсионного бурового раствора при разбуривании глинисто-аргиллитовых пород Волго-Уральского региона / И.А. Четвертнева, Е.В. Беленко, И.Ф. Гайсин, Г.А. Тептерева, С.Ю. Шавшукова // Транспорт и хранение нефтепродуктов и углеводородного сырья. - 2019. № 1. - C. 34-37. DOI: 10.24411/0131-4270-2019-10107

19. Новые подходы к оценке ингибирующих свойств инвертно-эмульсионных буровых растворов / И.Л. Некрасова, П.А. Хвощин, О.В. Гаршина, Г.В. Конесев // Строительство нефтяных и газовых скважин на суше и на море. - 2017. № 2. - C. 28-34.

20. Zhaohui S. Application of Drilling Fluids of Saturated Composite Salt Water in Well Li97 [J] // Sino-Global Energy. - 2011. - Vol. 2.

21. Nanotechnology to improve sealing ability of drilling fluids for shale with micro-cracks during drilling / G. Li [et al.] // SPE international oilfield nanotechnology conference and exhibition. Society of Petroleum Engineers, 2012. DOI: 10.2118/156997-MS

22. New Strong Inhibitory Polyamine Drilling Fluid System Research in Yubei Area / W.L. Huang [et al.] // Advanced Materials Research. - Trans Tech Publications Ltd, 2013. - Vol. 807. - P. 2519-2522. DOI: 10.4028/www.scientific.net/AMR.807-809.2519

23. Application of Oil-based Drilling Fluid in Unconventional Oil-gas Reservoirs, Zhongyuan Oilfield [J] / L. Minghua [et al.] // Sino-Global Energy. - 2013. - Vol. 7.

24. Application of anti-collapse aluminum matrix drilling fluid system in Jilin oilfield / M. Chao [et al.] // ICPTT 2012: Better Pipeline Infrastructure for a Better Life. - 2013. P. 196-208. DOI: 10.1061/9780784412619.023

25. Calvin Lowrans C.L. Optimising drilling fluid to maintain mudstone formation stability. -2012 . -34 p. 
26. Research of oil-based drilling fluids to improve the quality of wells completion / M.V. Nutskova [et al.] // IOP Conference Series: Materials Science and Engineering. - IOP Publishing, 2019. - Vol. 666, № 1. - P. 012065. DOI: 10.1088/1757-899X/666/1/012065

27. Podoprigora D., Raupov I. Research of the influence of polymeric drilling mud on the filtration-capacitive properties of polymictic sandstones // Acta Technica CSAV (Ceskoslovensk Akademie Ved). - 2018. - Vol. 63, № 4. - P. 537-546.

28. Капитонов В.А., Федосенко О.В., Юрченко В.В. Рассмотрение факторов, влияющих на устойчивость аргиллитов // Нефть. Газ. Новации. - 2017. - № 10. - С. 22-25.

29. Алиев А.Ф., Агзамов Ф.А. Анализ процесса бурения скважины под техническую колонну на месторождениях им. Р. Требса и А. Титова // Строительство нефтяных и газовых скважин на суше и на море. - 2018. - № 9. - С. 9-14. DOI: $10.17122 /$ ntj-oil-2017-4-52-62

30. Четвертнева И.А., Беленко Е.В., Гайсин И.Ф. Особенности бурения глинисто-аргиллитовых пород ВолгоУральского региона // Нефть. Газ. Новации. - 2019. - № 6. - С. 49-52.

31. Широков М.Н. Исключительная стабильность ствола скважины: что делать, когда не работает повышение плотности бурового раствора? // Бурение и нефть. - 2019. - № 9. - С. 46-49.

32. Santarelli F., Dardeau C., Zurdo C. Drilling through highly fractured formations: A problem, a Model, and s Cure // Journal of petroleum technology. - 1992. - № 24592. - 10 p.

33. Васильченко С.В., Потапов А.Г., Гноевых А.Н. Современные методы исследования проблемы неустойчивости глинистых пород при строительстве скважин. - М.: ИРЦ Газпром, 1998. - 83 с.

34. Дир 3.У.А., Хауи Р.А., Зусман Д. Породообразующие минералы. - М.: Мир, 1966. - Т. 3. - 318 с.

35. Баранов В.С. Глинистые растворы для бурения скважин в осложненных условиях. - М.: Гостопттехиздат, 1955. - 254 с.

36. Городнов В.Д. Физико-химические методы предупреждения осложнений в бурении. - М.: Недра, 1984. - 229 с.

37. Приклонский В.А. Грунтоведение. - М.: Госгеолитиздат, 1949. - Т. 1. - 400 с.

38. Грей Дж.Р., Дарли Г.С. Состав и свойства буровых агентов (промывочных жидкостей). - М.: Недра, 1985. - 509 с.

39. Кистре Э.Г. Химическая обработка буровых растворов. М.: Недра, 1972. - 392 с.

40. Ржевский В.В., Новиков Г.Я. Основы физики горных пород. - М.: Недра, 1973. - 211 с.

41. Ангелопуло О.К., Подгорнов В.М., Аваков В.Э. Буровые растворы для осложненных условий. - М.: Недра, 1988. - 135 с.

42. Шерстнев Н.М., Расизаде Я.М., Ширинзаде С.Я. Предупреждение и ликвидация осложнений в бурении. М.: Недра, 1979. - 297 с.
43. Войтенко В.С. Управление горным давлением при бурении скважин. - М.: Недра, 1985.- 180 с.

44. Пеньков А.И. Влияние полимеров на ингибирование глин // Нефтяное хозяйство. - 1979. - № 5.

45. Новиков В.С. Устойчивость глинистых пород при бурении скважин. - М.: Недра, 2000. - 270 с.

46. Применение безглинистых полимерсолевых растворов / Н.И. Крысин, М.Р. Мавлютов, А.М. Ишмухаметова [и др.]. - Пермь, 1982. - 64 с.

47. Ипполитов В.В., Севодин Н.М., Усынин А.Ф. Обеспечение устойчивоси глинистых пород при бурении наклонно-направленных скважин на месторождениях северной части Западной Сибири // Вестник Ассоциации буровых подрядчиков. - 2000. - № 2. - С. 13-18.

48. Мухин Л.К. Буровые растворы на углеводородной основе для бурения в осложненных условиях и вскрытия продуктивных пластов: дис. ... д-ра техн. наук. - М.: МИНХ и ГП, 1971. - 148 с.

49. Исследование технико-технологических факторов, определяющих устойчивость кыновскиих аргиллитов при бурении скважин / Т.Н. Бичкурин, И.Г. Юсупов, Р.С. Габидуллин [и др.] // Нефтяное хозяйство. - 2000. - № 12 . С. 25-27.

50. Тахаутдинов Ш.Ф., Бикчурин Т.Н., Юсупов И.Г. Исследование по разработке технологии вскрытия кыновского горизонта под большим зенитным углом // Нефтяное хозяйство. 2003. - № 3. - С. 35-39.

51. Юсупов И.Г. Физико-геологические исследования явлений обвалообразования неустойчивых горных пород при бурении скважин и меры их предотвращения: дис. ... канд. техн. наук. М.: МИНХ им. Губкина, 1966.

52. Гамзатов С.М. Влияние осмотического явления на кавернообразования // Бурение. - 1974. - № 8 . C. 16-18.

53. Forsans T.M., Schmitt L. Capillary forces: the neglected factor in shale instability studies? // EUROCK'94. - Balkema, Rotterdam, 1994. - Vol. 71. DOI: 10.2118/28029-MS

54. Cheng F.A., Lu A. New technique for evaluation of shale stability in the presentce of polymeric drilling fluid // SPE Production Engineering. - 1988. - Vol. 3, № 3. - P. 366-374. DOI: $10.2118 / 14249-P A$

55. Chenevert M.E. Glycerol mud additive provides shale Stability // Oil and Gas J. - YII. 87, № 29. - P. 60, 61, 64.

56. Рябинкина Н.Н., Валяева О.В. Состав и органическое вещество аргиллитов нижнего карбона Печорского бассейна // Нефтегазовая геология. Теория и практика [Электронный pecypc]. - 2017. - T. 12, №1. - URL: www.ngtp.ru/rub/1/2_2017.pdf (дата обращения: 10.02.2020).

Please cite this article in English as:

Nutskova M.V., Chudinova I.V., Sobolev A.N. Study of the mechanism of increasing the wellbore stability during fractured mudstone drilling. Perm Journal of Petroleum and Mining Engineering, 2020, vol.20, no.3, pp.231-241. DOI: 10.15593/2712-8008/2020.3.4

Просьба ссылаться на эту статью в русскоязычных источниках следующим образом:

Нуцкова М.В., Чудинова И.В., Соболев А.Н. Исследование механизма повышения стабильности ствола скважины при бурении трещиноватых аргиллитов // Недропользование. - 2020. - Т.20, №3. - C.231-241. DOI: 10.15593/2712-8008/2020.3.4 